\title{
Pulmonary hypertension diagnosed by echocardiography during idiopathic myelofibrosis
}

\section{A case report and a brief review of the literature Ipertensione polmonare diagnosticata con l'ecocardiografia in corso di mielofibrosi idiopatica Descrizione di un caso e breve revisione della letteraura}

\author{
Claudio Perrone ${ }^{1}$, Roberto Cartolari ${ }^{1}$, Beatrice Lupi ${ }^{2}$, Sergio Morelli ${ }^{2}$ \\ 'Respiratory Function Unit, ASL Viterbo, Presidio Ospedaliero Centrale "Belcolle", Viterbo, Italy \\ 2Department of Internal Medicine, Policlinico Umberto I, University "Sapienza", Rome, Italy
}

\begin{abstract}
Idiopathic myelofibrosis is a rare chronic myeloproliferative disease leading to extramedullary hematopoiesis (myeloid metaplasia) with splenomegaly. The liver and less frequently other organs including the lung can be involved, therefore portal hypertension is relatively common. Pulmonary hypertension (PH) is only occasionally reported, although recent studies have suggested an association between $\mathrm{PH}$ and myeloproliferative disorders.

We present a case of $\mathrm{PH}$ diagnosis by echocardiography in a patient affected by idiopathic myelofibrosis with portal hypertension.
\end{abstract}

Keywords: Echocardiography, idiopathic myelofibrosis, portal hypertension, pulmonary hypertension.

\section{RIASSUNTO}

La mielofibrosi idiopatica è una rara forma di malattia mieloproliferativa che porta ad una ematopoiesi extramidollare (metaplasia mieloide) con splenomegalia. Possono essere coinvolti più organi, compreso il polmone, ma il bersaglio d'elezione è il fegato ed un'ipertensione portale risulta perciò relativamente frequente. Un'ipertensione polmonare è stata invece segnalata solo occasionalmente, nonostante alcune recenti segnalazioni suggeriscano una connessione tra malattie mieloproliferative ed ipertensione polmonare.

Viene qui riportato un caso di ipertensione polmonare dia- gnosticata con ecocardiografia in un paziente affetto da mielofibrosi idiopatica con ipertensione portale.

Parole chiave: Ecocardiografia, ipertensione polmonare, ipertensione portale, mielofibrosi idiopatica.

\section{INTRODUCTION}

'Idiopathic myelofibrosis' (IM), 'agnogenic myeloid metaplasia' or 'myelofibrosis with myeloid metaplasia' are synonymous for a rare chronic myeloproliferative disease. Although the exact molecular and pathogenic mechanisms are not defined, a clonal defect in bone marrow stem cells leads to extramedullary hematopoiesis (myeloid metaplasia) with splenomegaly. This phenomenon can involve the liver, and less frequently other organs including the lung $[1,2]$. Considering the course of the disease, portal hypertension $(\mathrm{POH})$ is relatively common. Pulmonary hypertension $(\mathrm{PH})$ is only occasionally reported [3-5], although recent studies have suggested an association between $\mathrm{PH}$ and myeloproliferative disorders [6]. Major prognostic indices at the current time are advanced age, anemia, hypercatabolic symptoms, leukocytosis or

$\equiv$ Claudio Perrone

Head, Respiratory Function Unit, ASL Viterbo, Presidio Ospedaliero Centrale "Belcolle"

Strada Sammartinese snc, 01100 Viterbo, Italia

email: claudiolvperrone@libero.it

Data di arrivo del testo: 07/01/2010 - Accettato dopo revisione: 06/07/2010

Multidisciplinary Respiratory Medicine 2010; 5(4): 267-270 
leukopenia, circulating blast cells, and cytogenetic abnormalities considered at risk for leukemic transformation [6].

We present a case of PH diagnosis by echocardiography in a patient affected by $\mathrm{IM}$ with $\mathrm{POH}$; possible pathogenic links are then debated on the basis of a brief review of the literature.

\section{CASE REPORT}

A 71 year-old woman was admitted to our hospital because of exertional dyspnea that had become progressive over the past month, atypical chest pain, mild peripheral edemas, and palpitations. There was no history of heart and/or lung disease, with the exception of two previous episodes of acute pneumonia, respectively two years and one year ago. Fifteen years earlier, diagnosis of IM had been made by means of a bone marrow biopsy; the patient then underwent hematological treatment in day hospital regime at our Institute; her current therapy was oncocarbide and allopurinol.

On admission, body temperature was $36.7^{\circ} \mathrm{C}$; blood pressure was 120/90 mm Hg, heart rate was $96 /$ min, rhythmic; breathing rate was $24 / \mathrm{min}$. A mild systolic murmur was audible on the right parasternal margin. Respiratory sounds were substantially normal. Inferior edge of the liver was palpable about $3 \mathrm{~cm}$ below the costal arch and the spleen reached the umbilicus. No ascites was detected. Slight peripheral edemas were present.

Hematological data included a white blood cell count of $12.8 \times 10^{3} / \mathrm{ml}$; hemoglobin was $7.2 \mathrm{~g} / \mathrm{dl}$. AST and ALP transaminases were elevated. Platelets were $268 \times 10^{3} / \mathrm{ml}$. C3 and C4 were normal. Lupus anticoagulant, antinuclear and anticardiolipin antibodies were negative. The assay for fibrinogen degradation products (FDP) was slightly positive (275 U, normal range up to $250 \mathrm{U}$ ). PT, PTT and fibrinogen values were within normal range. Spirometry showed a slight restrictive pattern (FEV $/$ FVC $105 \%$, TLC $83 \%$ of predicted) with normal $\mathrm{DL}_{\mathrm{CO}}$ (performed after repeated transfusions of blood, to reach a hemoglobin concentration of about $11 \mathrm{~g} / \mathrm{dl}$ ). Arterial blood gas analysis showed $\mathrm{pH}$ 7.46, $\mathrm{pO}_{2}$ was $56 \mathrm{~mm} \mathrm{Hg}$, $\mathrm{pCO}_{2}$ was $29.7 \mathrm{~mm} \mathrm{Hg}$; $\mathrm{SaO}_{2}$ was $91.0 \%$, and bicarbonate concentration was $21.4 \mathrm{mmol} / \mathrm{L}$.

ECG showed normal sinus rhythm and incomplete right bundle branch block. Pattern S1, Q3, T3 was not present. Echocardiography showed enlarged right cardiac chambers, while left chambers were normal: a severe tricuspid valve insufficiency was detected and estimated pulmonary artery systolic pressure was $85 \mathrm{~mm} \mathrm{Hg}$. Pulsed wave Doppler and Tissue-Doppler Imaging at the mitral valve annulus level did not show other than first-degree left ventricular diastolic dysfunction, compatible with the age of the patient. Pulmonary function tests revealed a slight deficit with restrictive pattern (total lung capacity $80 \%$ of predicted maximum) without significant reduction in $\mathrm{DL}_{\mathrm{co}}$. Chest $\mathrm{X}$-ray and computerized tomography (CT) before and after contrast showed enlarged cardiac silhouette but normal lung parenchyma. Lung scan resulted consistent with a very low probability of pulmonary thromboembolism. Color-Doppler abdomen ultrasonography confirmed homogeneous liver enlargement, splenomegaly, and clear signs of $\mathrm{POH}$. Color-flow Doppler of leg veins was normal. Right heart catheterization was not performed for technical reasons.

Immediate transfusions of red blood cells were administered, and therapy by oxygen, furosemide, spironolactone and warfarin was started, obtaining mild improvement of symptoms. Two weeks later the patient was discharged with a prescription of furosemide, nifedipine (systemic blood pressure was increased) and warfarin. Bosentan was ruled out because of high levels of liver transaminases. A check up 20 days later with Doppler ECG estimated pulmonary artery systolic pressure to be $70 \mathrm{~mm} \mathrm{Hg}$. We lost the patient at follow up; we know that she died three months later from sepsis.

\section{DISCUSSION}

Dyspnea is a frequent symptom of IM, but it is usually related to abdominal discomfort or anemia. When it depends on like-pneumonia foci of interstitial pulmonary hematopoiesis, $\mathrm{PH}$ is not necessarily detected [7]. Even hypoxia is not always related to $\mathrm{PH}$; a case of fatal respiratory failure during IM has been reported, but pulmonary artery pressure levels were not reported [8]. Our patient on admission referred two previous episodes of pneumonia, but radiological documentation was not available. However, X-ray, high-resolution CT, and lung scan during recovery resulted negative for lung involvement. Other symptoms of $\mathrm{PH}$, e.g. exertional dyspnea, palpitations, chest pain, syncope and peripheral edema, are equally non specific and diagnosis is often delayed [9]. Notably all of these symptoms, with the exception of syncope, were reported by our patient. Moreover PH has an important prognostic relevance: Dingli et al. [10] reported a median survival of 18 months after the diagnosis. In this setting, echocardiography is a precious tool to detect non invasively $\mathrm{PH}$, although a hypermetabolic state must be considered in some cases with high cardiac output and elevated pulmonary artery pressure without an increased pulmonary artery resistance - to be evaluated by right heart catheterization [10]. Although to date $\mathrm{PH}$ has been reported only in a few cases of IM, a link is confirmed by the greater incidence of $\mathrm{PH}$ and more advanced age of onset with respect to the general population [11].

Pathogenic mechanisms of this association remain speculative.

Thrombocytosis, hypercoagulable states and erythroblastosis have been advocated in the genesis of PH during IM [4,9,11]; a pro-thrombotic status in IM is suggested by hematological and clinical events (portal vein thrombosis, deep vein thrombosis, amaurosis fugax, digital arterial thrombosis). Nevertheless in our patient the platelet count was 
FIGURA 1: CHEST X-RAY OF THE PATIENT IN SUPINE POSITION

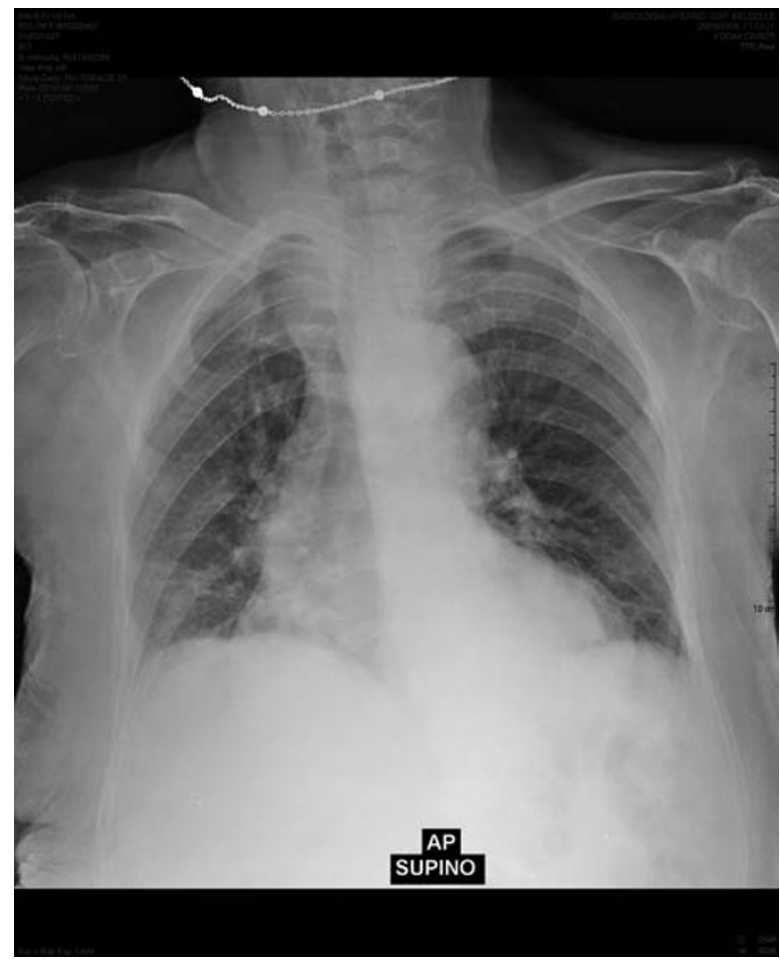

normal, and in the absence of evident thrombosis other mechanisms seem to be excluded by data regarding coagulation; moreover both $\mathrm{CT}$ and lung scan were not consistent with the suspicion of pulmonary thromboembolism, raised by a slight positivity of assay for FDP. Without pulmonary angiography, however, microthrombosis of pulmonary circulation cannot be excluded absolutely.

Auto-immunity is relevant for $\mathrm{PH}$ during systemic connective tissue diseases (i.e. systemic lupus erythematosus) [12], but also during liver cirrhosis [13], and it has been documented in IM [14]. However, in this patient all indices of auto-immunity resulted negative.

In fact, a significant proportion of cases of IM are affected by $\mathrm{POH}$. In chronic liver diseases (i.e. liver cirrhosis) $\mathrm{PH}$ may be associated with $\mathrm{POH}$ [15], i.e. porto-pulmonary syndrome. Gut-derived toxins, bypassing hepatic detoxification, could determine pulmonary arterial vasoconstriction. Although rare cases exist of $\mathrm{PH}$ and liver cirrhosis without $\mathrm{POH}$ [16], some undetectable degree of porto-systemic shunt cannot be excluded, and justifies also those cases of IM without detection of portal hypertension reported in the literature; furthermore an early splenectomy, frequently performed in IM with $\mathrm{POH}$, could hypothetically prevent $\mathrm{PH}$. The fact however remains of cases of $\mathrm{PH}$ occurring in IM after splenectomy.

Changing perspective, Popat et al. $[17,18]$ identified myelofibrosis as a complication of presenting $\mathrm{PH}$, primary or secondary. In idiopathic pulmonary arterial hypertension clonal proliferation of endothelial cells can occur: the articles debate the possibility of a possible correlation with blood stem cells, but data propend for a non clonal proliferation and a reactive process, differentiating this "secondary" myelofibrosis from IM. Although in our patient diagnosis of IM had been made by bone marrow biopsy, the observations of Popat et al. are of absolute interest, raising new doubts and a new possible hypothesis; however it seems mandatory to search for myelofibrosis in patients affected by $\mathrm{PH}$ (the association seems significant) and to verify what the type of myelofibrosis is (idiopathic or secondary?).

\section{CONCLUSION}

In conclusion, an association seems to exist between $\mathrm{PH}$ and $\mathrm{IM}$, but the nature of this link remains unclear. A correlation with $\mathrm{POH}$, hypothesized in the past, is fascinating but not completely clarified, and not always detectable; new mechanisms are continuously being proposed and further data are needed to establish the exact relationship between $\mathrm{PH}$ and IM. Moreover a significant incidence of "secondary", reactive myelofibrosis has been reported in $\mathrm{PH}$. In all cases patients with $\mathrm{PH}$ show a severe prognosis, and Doppler echocardiography should be performed at the initial stage to achieve an early diagnosis.

CONFLICT OF INTEREST STATEMENT: None of the authors has any conflict of interest to declare in relation to the subject matter of this manuscript.

\section{References}

1. Tefferi A. Myelofibrosis with myeloid metaplasia. N Eng J Med 2000;342:1255-1265.

2. Mesa RA, Barosi G, Cervantes F, Reilly JT, Tefferi A. Myelofibrosis with myeloid metaplasia: disease overview and non-transplant treatment options. Best Pract Res Clin Haematol 2006;19:495-517.

3. Gaine SP, Rubin LJ. Primary pulmonary hypertension. Lancet 1998;352:719-725.

4. Marvin KS, Spellberg RD. Pulmonary hypertension secondary to thrombocytosis in a patient with myeloid metaplasia. Chest 1993;103:642-644.

5. Coates GG, Eisenberg B, Dail DH. Tc-99m sulfur colloid demonstration of diffuse pulmonary interstitial extramedullary hematopoiesis in a patient with myelofibrosis. A case report and review of the literature. Clin $\mathrm{Nucl}$ Med 1994;19:1079-1084.

6. Guilpain P, Montani D, Damaj G, Achouh L, Lefrère F, Le Pavec J, Marfaing-Koka A, Dartevelle P, Simonneau G, Humbert M, Hermine O. Pulmonary hypertension associated with myeloproliferative disorders: a retrospective study of ten cases. Respiration 2008;76:295-302.

7. Tefferi A. The forgotten myeloproliferative disorder: myeloid 
metaplasia. Oncologist 2003;8:225-231.

8. Rumi E, Passamonti F, Boveri E, De Amici M, Astori C, Braschi M, Castagnola C, Magrini U, Cazzola M, Lazzarino $M$. Dyspnea secondary to pulmonary hematopoiesis as presenting symptom of myelofibrosis with myeloid metaplasia. Am J Hematol 2006;81:124-127.

9. Yamauchi K, Shimamura K. Pulmonary fibrosis and sea-blue histiocyte infiltration in a patient with primary myelofibrosis. Eur Respir J 1995;8:1620-1623.

10. Dingli D, Utz JP, Krowka MJ, Oberg AL, Tefferi A. Unexplained pulmonary hypertension in chronic myeloproliferative disorders. Chest 2001;120:801-808.

11. García-Manero G, Schuster SJ, Patrick H, Martinez J. Pulmonary hypertension in patients with myelofibrosis secondary to myeloproliferative diseases. Am J Hematol 1999;60:130-135.

12. Perez HD, Kramer N. Pulmonary hypertension in systemic lupus erythematosus: report of four cases and review of the literature. Semin Arthritis Rheum 1981;11:177-181.

13. Morrison EB, Gaffney FA, Eigenbrodt EH, Reynolds RC, Buja LM. Severe pulmonary hypertension associated with macronodular (postnecrotic) cirrhosis and autoimmune phenomena. Am J Med 1980;69:513-519.

14. Lang JM, Oberling F, Mayer S, Heid E. Auto-immunity in primary myelofibrosis. Biomedicine 1976;25:39.

15. Robalino BD, Moodie DS. Association between primary pulmonary hypertension and portal hypertension: analysis of its pathophysiology and clinical, laboratory and hemodynamic manifestations. J Am Coll Cardiol 1991;17:492-498.

16. Yoshida EM, Erb SR, Ostrow DN, Ricci DR, Scudamore CH, Fradet G. Pulmonary hypertension associated with primary biliary cirrhosis in the absence of portal hypertension: a case report. Gut 1994;35:280-282.

17. Popat U, Frost A, Liu E, May R, Bag R, Reddy V, Prchal JT. New onset of myelofibrosis in association with pulmonary arterial hypertension. Ann Intern Med 2005;143:466-467.

18. Popat U, Frost A, Liu E, Guan Y, Durette A, Reddy V, Prchal JT. High levels of circulating CD34 cells, dacrocytes, clonal hematopoiesis, and JAK2 mutation differentiate myelofibrosis with myeloid metaplasia from secondary myelofibrosis associated with pulmonary hypertension. Blood 2006,107:3486-3488. 